\title{
NEW YORK AND PHILADELPHIA MOTOR BUSES.
}

\section{A DESCRIPTION OF THE GASOLINE AND ELECTRIC AUTOMOBILES NOW USED FOR PUBLIC TRANSPORTATION.}

\section{B Y H A R R Y W. P E R R Y.}

THE motor omnibus, which has become such a prominent feature of street traffic during the last three years in London, where more than 900 are now operating on regular routes and schedules, made its debut in America last summer. It has entirely superseded the old horse stages that formerly supplied the only form of regular public vehicular conveyance on Fifth Avenue in New York city. From the start the motor omnibus service proved attractive to the public, and up to the present time its popularity has been at tested by the fact that the buses usually carry passengers enough to fill most of the seats on every trip. After experimenting at considerable expense with American-built motor omnibuses of various types, all experimental, during a period of seven or eight years, French De Dion bus of 190 1907, the Fifth Avenue Coach Company put in regular service in the months of July and August last year fifteen De Dion buses of 1906 model like those shown in one of the accompanying illustrations. The running gears and machinery were imported from London, having been bought from the English agents of front axle and round solid rear axle. The front wheels are 34 inches in diameter and the rear pair 39 inches, over the tires. Solid rubber tires of American manufacture are fitted all around, the rear pair being of the twin type, to reduce any tendency toward skidding and to increase the life of the tires.

Connection between the engine and transmission system is made by a disk clutch having one steel and two brass disks. The change-speed mechanism is of the selective sliding-gear type, giving four forward speed ratios and one reverse. This is mounted in an aluminium alloy gear case with the two shafts in a vertical plane. The transmission gears and bearings are lubricated with the same oil as the engine cylinders and bearings, which is pumped onto the gears from slots in the case by a worm-geared pump. Drive is by bevel gearing to a bevel gear differential on the colntershaft which runs on ball bearings. In stead of using roller chains for final drive to the rear road wheels, the ends of the countershaft are fitted with spur pinions that mesh with internal gears secured to the inside of the wheels. The brake lever
When the additional equipment is received, it is the intention of the company to extend the service to several cross-town streets and to routes in Harlem, eventually operating the motor buses from Bleecker Street down town, north to the Harlem River at 155th Street and Central Bridge.

Philadelphia, despite her traditional slowness, was a close second to New York in adopting motor omnibuses. On July 16 last fourteen new double-deck machines, with bodies built after the same design as the New York buses, began running on a seven-minute headway on a five-mile route extending from Spruce Street north on Broad Street to Diamond Street, thence to Fairmount Park. During the first two days, when the Elks' Carnival was in progress, 5,000 passengers rode in the new omnibuses, and on the first Sunday, July 21, 15,000 persons were carried. Since that time the number of machines has been increased to twenty-five, which run on a four-minute headway, They are operated by the Auto Transit Company, which sought for a year to secure a franchise that was granted only last summer. A five-cent fare is

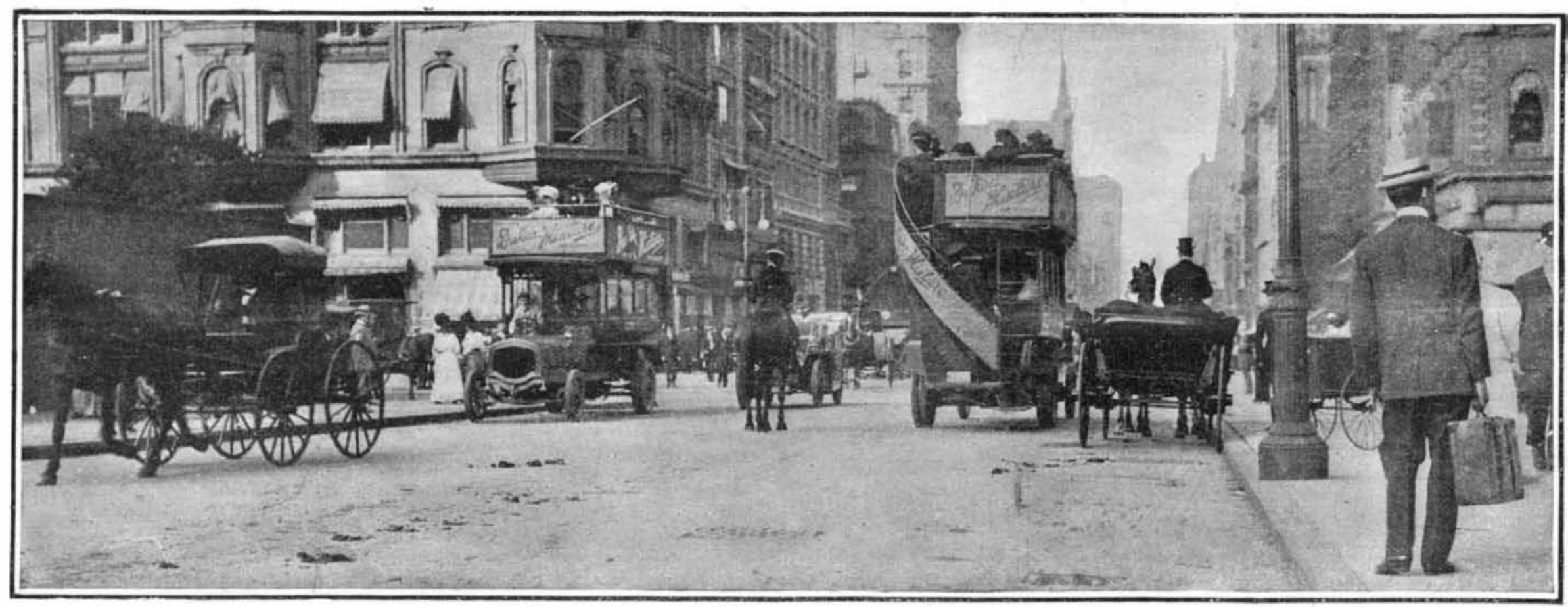

THE DE DION BUSES USED ON FIFTH AVENUE.

NEW YORK AND PHILADELPHIA MOTOR BUSES.

the French factory, and were brought over unassembled. The chassis were assembled in New York and fitted with bodies built in Philadelphia by the wagon and stage body-building firm of Fuller \& Walker after the designs of the English bodies. The bodies are of the double-deck type so popular in the large cities of Europe. They have seats for thirty-four passengerssixteen inside and eighteen on the upper deck.

These De Dion omnibuses have an overall length, from starting crank to rear lamp bracket, of 23 feet 4 inches, and an extreme width of 7 feet 4 inches. The maximum height is 12 feet 2 inches. The inside body dimensions are 11 feet 2 inches long by 5 feet 3 inches wide. The body is carried on a running gear having a wheelbase of 13 feet 101/2 inches and tread of 5 feet 8 inches. Total weight of the omnibus complete without passengers is approximately 7,900 pounds, and when filled, about 13,000 pounds.

The prime mover is a De Dion gasoline engine of 100 millimeters bore and 130 millimeters stroke (approximately 4 by 5 inches) having a French rating of 24 horse-power and an English rating of 28 horsepower. The cylinders are cast separately and have integral water jackets with brass caps. An oil reservoir and pump are located in the base of the crank case Magneto ignition is employed, with high-tension distributing system and low-tension interrupter. A primary battery is used only for starting. The engine develops its maximum efficiency at a speed of 2,000 revolutions per minute, but it can be throttled down practically to 300 or 850 revolutions. The radiator is of the fin-tube type, located at the extreme ront of the vehicle.

The frame of the chassis is of pressed steel, wood filled. This is . mounted on a square-section solid- is interconnected with the engine throttle, so that the throttle is closed as the brakes are set, thus shut ting off the power.

Since the buses were put in operation, they have been equipped with acetylene gas tanks and lamps fo interior illumination

In addition to the De Dion omnibuses that are now in service, the Fifth Avenue Coach Company has contracted for eleven more motor buses, ten of which are to be built in the United States according to specifications prepared by the company's own engineers.

Two hundred head of horses and forty-five stages were displaced by the motor buses now in operation, and were sold by the operating company in the latter part of July. The route covered extends from Washington Square to 90th Street on Fifth Avenue, a di tance of more than four miles. The buses run on five-minute headway, and the schedule allows one hour for the round trip, including stops and a wait of five minutes at each end. This calls for an average speed of ten miles an hour, including stops, whereas the old horse stages were allowed one and one-half hours to cover the route both ways. During the first six month of the new service it was found that the motor buse maintained their schedule, whereas the horse stages often exceeded their time allowance.

The present buses begin running at 7 o'clock A. M and stop at 11 P. M. Each makes from fourteen to sixteen trips a day, and is manned during that period by two crews of driver and conductor. When all of the seats are filled, no more passengers will be taken on. A single-trip fare of ten cents is charged. If al of the seats in each bus were filled once on each trip the present service could carry more than 15,000 passengers a day. charged, and the vehicles run from $5.30 \mathrm{~A}$. M. to midnight

The Philadelphia omnibuses are of domestic manufacture, being built by the Commercial Truck Company of America, with headquarters in Philadelphia and a large manufacturing plant in a nearby city. All of these vehicles are electric, and they represent the most extensive attempt ever made to utilize the four-wheel-drive principle. The storage battery that supplies the power is carried underneath the body, and each of the four road wheels is driven by an electric motor. Each motor is carried in a fork at the end of the axle, and to provide for steering, the front motors have trunnions on the top and bottom of the motor casing which engage with the yoke ends of the axle, making a swivel joint similar in action to the ordinary steering knuckle. Suitable arms are cast on the motor frame, to which are connected the steering rods. The wheel spindle is a casting of nickel steel, and is bolted to the motor frame. Steering is by hand wheel with screw-type irreversible gear. The axles are of cast nickel steel. Double-reduction gears furnish the drive from the motor armature to the wheel. The motors are manufactured by the Commercial Truck Company and are rated at 22 amperes, 85 volts.

The batteries used consist of forty-two Exide cells, each of which contains $21 \mathrm{M}$. V. plates of the pasted type. These cells are of sufficient capacity to give a liberal margin of safety for running three round trips, which amount to approximately thirty miles.

With a wheelbase of $10 \frac{1}{2}$ feet and trea of 5 feet 10 inches, these electric buses have an overall length of 19 feet. Their weight empty is 11,500 pounds.

A large garage and power house has just been 
erected by the Auto Transit Company at Thirty-third and Dauphin Streets for the storage of the vehicles and recharging of their batteries. By means of spe cial machinery the discharged battery can be removed from a vehicle and a freshly-charged battery substituted for it in two or three minutes.

New York and Philadelphia are the only American cities that at present have a regular motor omnibus service, but a company in San Francisco has recently been advertising extensively in the local daily newspapers its proposal to start such a service in that city, and offering to sell some thousands of shares of stock at five cents a share. If the intentions are bona fide, this indicates an awakening of interest in the subject on the Pacific coast. The earthquake two years ago gave a powerful impetus to automobiles, especially for utility purposes, in that city, and this fact, together with the succeeding street-car strike, would naturally incline the public there to look with favor upon the introduction of motor omnibuses.

Europe is several years ahead of the United States in the use of motor buses. In London alone more than 900 such vehicles are now being operated by fourteen omnibus companies. These run over regular routes to all important nearby suburbs on regular time schedules. The 800 that were in use in 1906 carried $184,000,000$ passengers in the twelve months, which was $4,000,000$ more than the London tramroads carried in the same time. Besides the omnibus service in the city, a number of the principal steam railroaḋs of England maintain motor bus lines as "feeders," operating between stations on the railroad and well-populated communities some distance off the line and not otherwise connected with it. Altogether, the railroads of the United Kingdom now operate nearly 270 motor buses and other styles of automobile passenger and freight vehicles. The Great Western Railroad alone has ninety motor buses, which up to June 20 last had run $1,600,000$ miles and carried a total of more than $3,500,000$ passengers. Some of its routes are twenty miles long. With the exception of a very few steam and electric vehicles, the motor buses in England are driven by gasoline or kerosene engines.

Doubtless the great activity that has prevailed and that still continues in electric railroad construction, the development of motor railroad cars by the steam roads for branch-line and short-haul work, and our notoriously bad public roads, will all tend to retard the development of motor omnibus and stage lines in the United States, yet it is reasonable to believe that we are just now entering upon a new era in passenge transportation. Although the English people have complained long and bitterly against the noise, clumsiness, and foul odors of many of the London buses, there is no doubt that the motor buses in use in New York are much quieter, and in many ways less objectionable than the street cars. Since they do not run on rails, and their self-contained and independent power plants render overhead or underground feed wires or rails unnecessary, it may easily be that as the motor omnibuses are further perfected, they will prove more economical and more convenient than street railroad systems, with their enormously expensive central power houses and installations of tracks and current wires, particularly in small cities and towns where the traffic is not heavy.

\section{RESULTS OF TEST OF AUTOMOBILE \\ TRUCKS BY THE FRENCH WAR DEPARTMENT.}

THE Automobile Club of France recently made the following report relating to the use of heavy automobiles in the military maneuvers of the southwest army. The cars were used for furnishing the supplies for the troops of the 18th army corps, and the tests were carried out under the general supervision of the Minister of War. A certain number of constructors placed forty machines at the disposition of the army, under conditions which were fixed in advance. As regards the service to be carried out, this consisted in transport ing each day to about 72 miles from Bordeaux the sup plies which were needed for the troops, representing a mean tonnage of 39 . The cars were divided into four sections which were composed so as to be as homogeneous as possible. One section was thus made up entirely of cars having iron tires. Sections 2 and 4 were detailed to carry the supplies on the even-numbered days and return empty on the odd-numbered days so as to be re-loaded and thus be ready to start the next morning. Sections 1 and 3 were to carry the supplies on the odd-numbered days and follow the same plan. Each day about 18 cars were used. The start took place at $5 \mathrm{~A}$. M. The supplying of the troops was carried out from 2 P. M. to 4 or 5 o'clock, after which the cars retired to a distance of 12 or 18 miles to camping points designated in advance. The next day, they reached Bordeaux about noon, and proceeded to the military storehouses in order to be loaded, after which they entered their headquarters where they were cleaned and looked over. The difficultles which were met with at Bordeaux as to the loading of the cars and the consequent late hour at which they came back to the garage, made this service quite laborious for the men and gave a hard strain upon the material. However, there were no important incidents to be noted in the course of the rout A single car, on account of an imperfect adjustmen

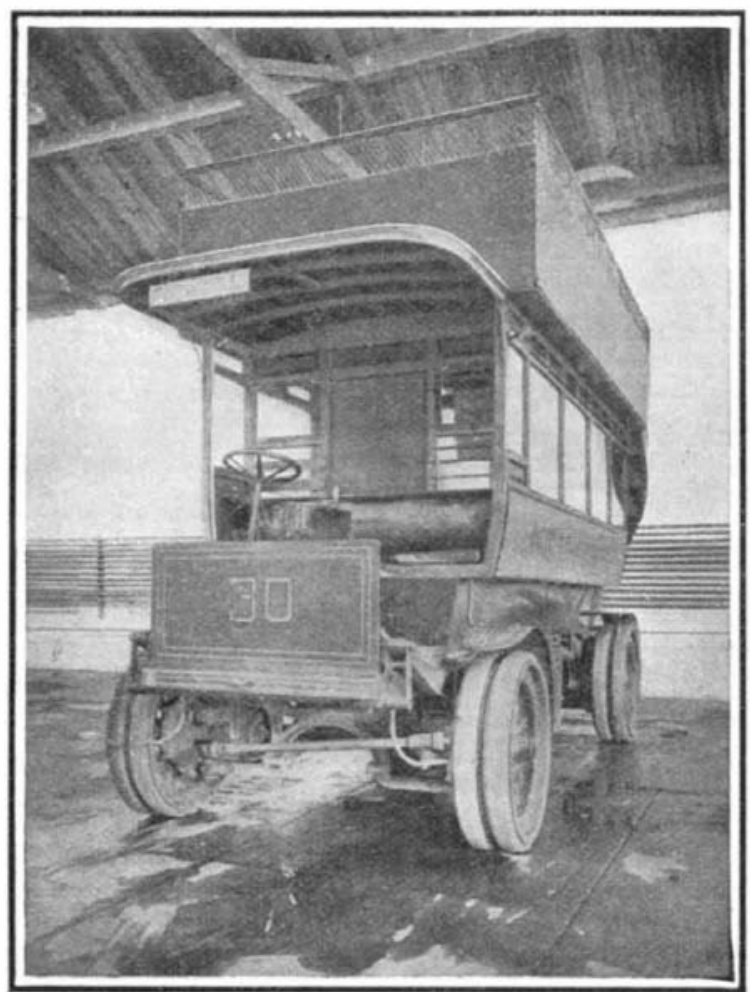

FRONT VIEW OF PHILADELPHIA ELECTRIC BUS,
SHOWING METHOD OF HANGING THE MOTORS.

the start, remained useless for several days. The most serious mishaps were engine troubles from the seizing of the connecting rods on the wrist pins. I seems likely that these accidents were due to exaggerated speeds, which, in spite of the orders, were made by some of the cars. In fact, although running in file the drivers of the most powerful cars, which normally were at the head of the line, accelerated their speed and the cars which were in the rear were obliged to exceed their normal speed in order to keep up with them. It will be easy to remedy these disadvantage by forming the sections of the convoys or an entire convoy of cars of the same make and quite uniform of work which is demanded from the cars. A lessening of the speed will correspond to a considerable lessening of the expense of maintenance, which at the present time is excessive.

Some interesting experiments as to carrying the wounded were also made during the maneuvers. Several cars, after having carried out the supplying of the troops, were sent to the hospital of Aiberac. Here they were furnished with straw and in them the wounded men were placed either sitting or lying. The cars left at once for Bordeaux, which they reached at 6 P. M., after having covered 150 miles without any trouble. The physicians charged with following the experiments declared that they were quite satisfied with the result.

Although many of them were far from being new, the solid rubber tires gave no trouble, and during the whole time of the maneuvers only one had to be replaced owing to a defect in the manufacture. The cars provided with iron tires behaved very well on this occasion, but unfortunately the short duration of the maneuvers will not allow of considering the results as decisive. However, a method which gave excellent results consists in placing rubber tires on the front wheels and iron tires on the rear. wheels. A car whose performance deserves great credit for endurance and regularity is one which used iron tires and had shockdampers in the front and rear. The consumption of fuel during the maneuvers was normal, and if we take account of the fact that one half of the course was made with the cars empty, the cost of the ton-mile net load was about equal to that determined during the trial of heavy cars held in May and June, 1907. However, it is to be noted that during the maneuvers, where the cars of the same power carried about the same loads and made the same stages at like speed, the steam cars had a mean fuel consumption about equal to that of the gasoline cars. To sum up, the Automobile Club expresses the opinion that from a military standpoint the experiment with hauling by motor cars during the maneuvers shows conclusively that mechanical traction can from now on replace animal traction, and its adoption, which will lighten up the army material considerably, will allow of easily solving the complicated problem of supplies and evacuation of troops in the field. From a general standpoint, it is seen that the manufacturers have established heavy cars which will render the greatest service in commerce and industry, and they are at present practical and often economical. It may

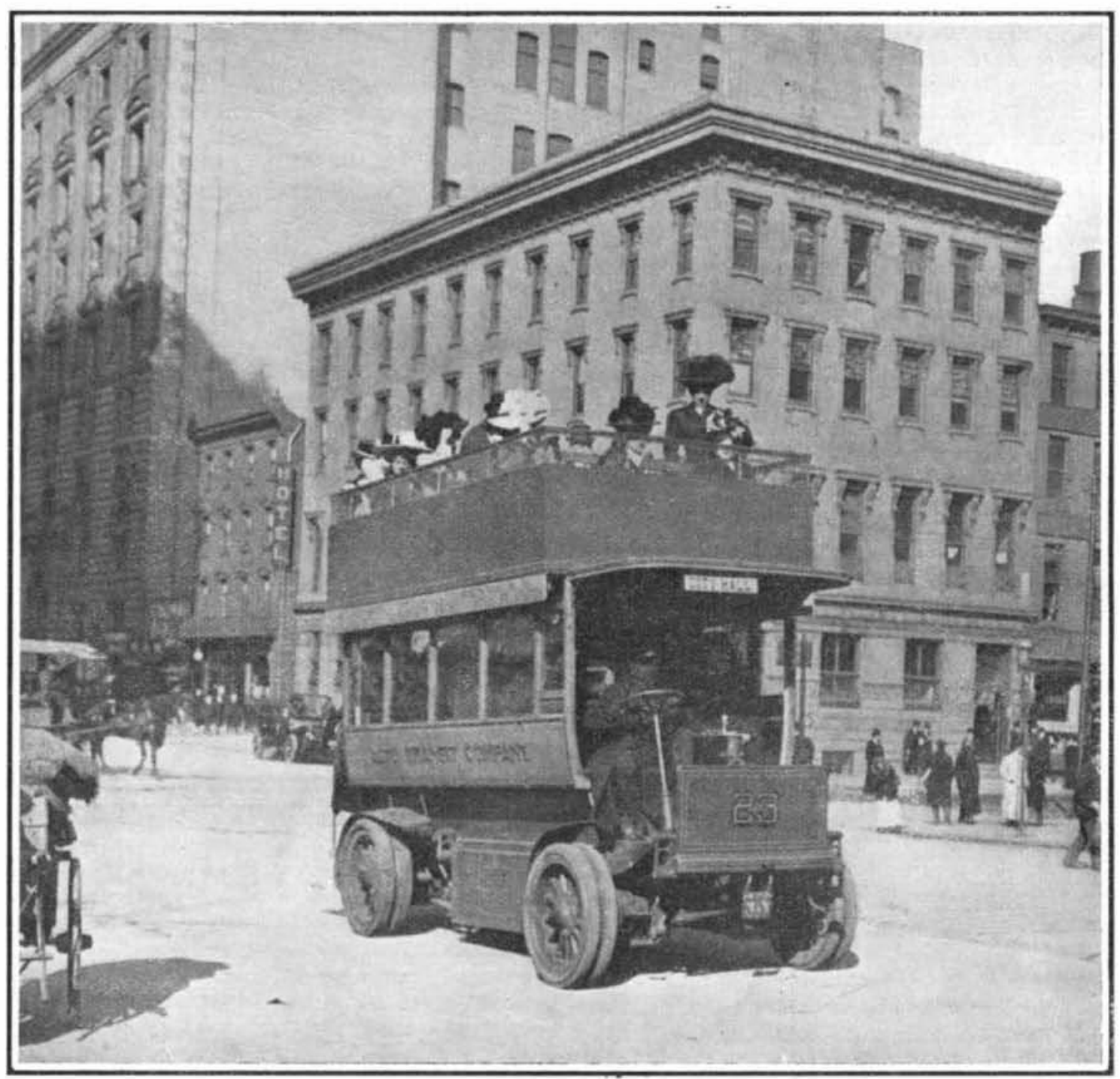

ONE OF THE DOUBLE-DECK ELECTRIC OMINIBUSES NOW IN SERVICE IN PHILADELPHIA. NEW YORK AND PHILADELPHIA MOTOR BUSES.

and also by a better training of the men. During the maneuvers it was found that in nearly every case the serious breakdowns were due to an excess of speed and it is to be hoped that the different constructor will be able to render this impossible by proper mechanical means so as to limit the speed to the kind be mentioned that the cars were of the leading French makes such as the De Dion, Mors, Panhard, LorraineDietrich, Darracq, 'Serpollet (steam), etc., ranging from 20 to 40 horse-power, and carrying a net load of two to five tons. Altogether, there were eight cars which belong to the War Department. 